\title{
Isolation and Proto-cooperation of Pseudomonas putida TS 18 from Water Calyx Fluid of Spathodea campanulata P. Beauv.
}

\author{
Martin Paul A. ${ }^{1 *}(\mathbb{D})$, Jayanthi D. ${ }^{2}(\mathbb{D})$ and Thamizhseran N. ${ }^{1}$ (D) \\ ${ }^{1}$ St. Joseph's College (Autonomous), Bengaluru - 560 027, India. ${ }^{2}$ Mount Carmel College, Autonomous, \\ Bengaluru - 560 001, India.
}

\begin{abstract}
The study was to isolate, characterize and identify bacteria present in the water calyx fluid of the African tulip, Spathodea campanulata P. Beauv. Nutrient agar and nitrogen free malate $(\mathrm{Nfb})$ semi-solid media were used to isolate the bacteria. Bacteria was identified using $16 \mathrm{~S}$ rDNA sequencing. Pseudomonas putida TS 18 was found to be a new strain based on highest homology during the BLAST. Morphological and biochemical characterization of the identified bacteria was done by routine methods. This is the first study to report bacteria from the water calyx fluid of $S$. campanulata. Identified bacteria along with fluid content might be playing a unique role in the flower development by showing nitrogen fixing potential under in vitro conditions.

Keywords: Water calyces; P. putida; $16 \mathrm{~S}$ rDNA sequencing.
\end{abstract}

*Correspondence: mart_paul18@yahoo.com

(Received: 17 August 2019; accepted: 17 October 2019)

Citation: Martin Paul A., Jayanthi D. and Thamizhseran N., Isolation and Proto-cooperation of Pseudomonas putida TS 18 from Water Calyx Fluid of Spathodea campanulata P. Beauv., J Pure App/ Microbiol., 2019; 13(4):2027-2033. https://doi.org/10.22207/ JPAM.13.4.14

(C) The Author(s) 2019. Open Access. This article is distributed under the terms of the Creative Commons Attribution 4.0 International License which permits unrestricted use, sharing, distribution, and reproduction in any medium, provided you give appropriate credit to the original author(s) and the source, provide a link to the Creative Commons license, and indicate if changes were made. 


\section{INTRODUCTION}

Water calyces are the peculiar structures produced by the Spathodea campanulata $\mathrm{P}$. Beauv., belonging to family Bignoniaceae from which the entire flower develops. The water calyces are ought to serve as a shield against floral herbivores; in protecting the sex organs from unfavourable consequences like high transpiration there by providing a cooling effect and also with antimicrobial activity (Jane et al. 2007; Burck, 1910; Killedar et al. 2011; Pat, 2011). Apart from its protective role, water calyces are ascribed to be beneficial to plant due to presence of endophytic microflora and biomolecules (Burck, 1910). Endophytic communities are vast and form microbial niches with in the host plant having direct influence on their growth, yield, by suppressing pathogenicity, solubilizing phosphate, synthesizing phytohormones and assimilating nitrogen to plants and (Monica et al. 2006). Not a single plant species is known to exist without endophytic colonization. Survival of the endophytic organisms inside the host plant involves complex physiological manipulations including majorly the bypass of plant defensive mechanism which is seen as a highest accomplishment by plant-colonizing bacteria (Gail MP, 2004). Most of the reports on endophytic communities in the last two decades are plant growth promoting microorganisms and their applications in the field of agriculture as modern organic biofertilizers (Vessey, 2003; Silva et al. 2006). Among which Bacillus and Pseudomonas forms are predominate (Podile, 2006) and one such dynamic plant growth promoting bacteria belongs to genus Pseudomonas which is heterogeneous and ecologically significant group among bacteria (Tasic et al. 2014). Various species of Pseudomonas are widely used as bioinoculant, biofertilization and phytostimulation (Wafa et al 2018). They are known to inhabit foliar surfaces, root surfaces, intercellular spaces in leaves and roots. Many of the aforementioned functionalities are known to be possessed by many species of Pseudomanas such as Pseudomonas aureofaciens, Pseudomonas chlororaphis, Pseudomonas fluorescens, Pseudomonas solanacearum, Pseudomonas stutzeri and Pseudomonas syringae. (Bernard, 2012; Islam et al. 2016). Similar kind of association is also assumed to be involved in the flower development of Spathodea campanulata.
The literature available on the water calyx fluid is largely confined to its mortality, mineral and nitrogen content, antimicrobial activity and biomolecules (Charyulu et al. 1990; Trigo et al. 2000; Martin et al. 2019, Jayanthi et al. 2019) But, the report and the role of bacteria within the water calyces still remains unexplored except for the findings of Treub (Burck, 1910). Hence, the present study was conducted to isolate, identify and indicate its role in the water calyx fluid.

\section{MATERIAL AND METHODS Sampling}

Freshly collected flower buds of $S$. campanulata of different flowering seasons were collected from different locations in the city of Bengaluru.

\section{Microscopic examination}

Preliminary microscopic examinations on the calyx fluid were carried out using Magnus MLX plus light microscope and Magnus phase contrast microscope. Gram staining, capsule staining and hanging drop technique for motility were conducted following routine microbial methods (James et al. 1999).

\section{Isolation}

For extracting calyx fluid, unopened floral buds were washed in distilled water to remove surface contaminants. Under in vitro condition, the floral buds were washed in $0.1 \%$ mercuric chloride for 10 minutes followed by three washes in autoclaved distilled water for 5 minutes. The flower buds were again surface sterilized with absolute alcohol. Using sterile syringe, calyx fluid from the calyces was extracted. Isolation of bacteria was carried out by inoculating loopful of calyx fluid on nutrient agar by spread plate technique. The plates were incubated at room temperature $28 \pm 2^{\circ} \mathrm{C}$ and observed for colony characters.

\section{Evaluation of isolate for PGPR potential}

The isolated bacterium from the nutrient agar plates was screened in vitro for various plant growth promoting properties such as nitrogen fixing ability on nitrogen free malate-semisolid media ( $\mathrm{Nfb}$ ). Loopful of calyx fluid was also inoculated directly in $\mathrm{Nfb}$ tubes. Pellicles obtained from $\mathrm{Nfb}$ tubes were sub-cultured further to obtain pure bacterial culture. 
Table 1. Biochemical characterization of the Pseudomonas putida TS 18

\begin{tabular}{lc}
\hline Biochemical & Results \\
Tests & \\
\hline Gram Staining & Negative rods \\
Motility & + \\
Capsule & + \\
Catalase & + \\
Oxidase & + \\
Starch hydrolysis & - \\
Lysine & - \\
Ornithine & - \\
Urease & - \\
TDA & - \\
Nitrate reduction & - \\
H S production & - \\
Glucose & + \\
Adonitol & - \\
Lactose & - \\
Arabinose & + \\
Sorbitol & - \\
Mannitol & + \\
Rhamnose & - \\
Sucrose & - \\
Indole & - \\
Methyl Red & - \\
Voges-Proskauer & + \\
Citrate Utilization & \\
\hline & - \\
Riohemical chanacterioation & \\
\hline
\end{tabular}

\section{Biochemical characterization}

The isolate from $\mathrm{Nfb}$ tubes were screened for gram staining, capsule staining, catalase, oxidase, starch hydrolysis and IMViC test (James GC, et al. 1999). Test for Lysine, ornithine, urease, TDA, nitrate reduction, $\mathrm{H}_{2} \mathrm{~S}$ production, carbohydrate utilization through glucose, adonitol, lactose, arabinose, sorbitol, mannitol, rhamnose, sucrose using HiAssorted Biochemical test kit KB001 and KB002.

\section{DNA Extraction}

Extraction of Genomic DNA of the isolate was done using Chromous Genomic DNA isolation kit (RKT09). Suspension buffer of $750 \mu$ l of $1 \mathrm{X}$ was mixed with $100 \mathrm{mg}$ of bacterial pellet followed by addition of $5 \mu \mathrm{l}$ of RNaseA with intermittent mixing for $5-6$ times followed by incubation at $65^{\circ} \mathrm{C}$ for 10 minutes. Later, lysis buffer of $1 \mathrm{ml}$ was added with intermittent mixing for 5-6 times and incubated at $65^{\circ} \mathrm{C}$ for 15 minutes. The mixture was centrifuged at $13000 \mathrm{~g}$ and the supernatant was collected in a $2 \mathrm{ml}$ vial. Supernatant was loaded onto the spin column and centrifuged at $13000 \mathrm{~g}$ for 1 minute at room temperature. The content of the collection tube was discarded. Then, $500 \mu \mathrm{l}$ of $1 \mathrm{X}$ wash buffer was added to the column and centrifuged at $13000 \mathrm{~g}$ for 3 minutes at room temperature. Later, the spin column was placed in a fresh $1.5 \mathrm{ml}$ vial followed by the addition of $50 \mu \mathrm{l}$ of warm elution buffer (kept at $65^{\circ} \mathrm{C}$ ) and centrifuged at $13000 \mathrm{~g}$ for 1 minute at room temperature. The eluted DNA was collected and electrophoresed on $1 \%$ agarose gel to estimate the quality and quantity of the extracted DNA with template used subsequently for PCR amplification.

\section{Amplification of 16S rDNA}

Amplification was done using 16s rRNA degenerative primers (16s Forward primer 5' CMGSCVTDACACAWGCHAGYC - 3' and Reverse primer 5' - GGCGSMTGWGTNCAAGSV - 3'). Polymerase chain reaction was carried out using $1 \mu$ l extracted DNA, $4 \mu$ l dNTPs Mix, $10 \mu$ l of $10 \mathrm{X}$ Taq DNA polymerase assay buffer, $1 \mu \mathrm{l}$ of Taq Polymerase enzyme $(3 U / \mu \mathrm{l})$ and with water to make up total reaction volume of $100 \mu l$. PCR was programed for 35 cycles with initial denaturation at $94^{\circ} \mathrm{C}$ for 5 minutes, denaturation at $94^{\circ} \mathrm{C}$ for 30 seconds, annealing at $55^{\circ} \mathrm{C}$ for 30 seconds, extension at $72^{\circ} \mathrm{C}$ for 90 seconds and final extension at $72^{\circ} \mathrm{C}$ for 7 minutes. The PCR product of about $1.4 \mathrm{~kb}$ size band was determined on $1 \%$ agarose gel electrophoresis (Fig. 1). All reagents used in the experiment were of Chromous make. DNA sequencing and identification

The amplified PCR product was subjected to Sanger's Dideoxy method of sequencing. This was carried out using ABI 3500 Genetic

\section{TS L}

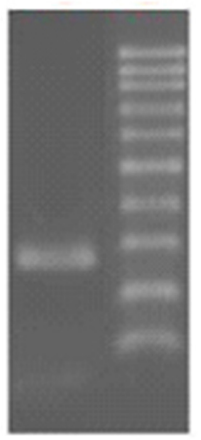

Fig. 1. Visualization of PCR amplified 16srDNA fragment ( 1.4kb) on $1 \%$ agarose gel. TS: amplified bacterial genomic DNA; L: 500bp DNA ladder. 
Analyzer. Sequencing reaction composed of BigDye terminator cycle sequencing kit-ready reaction mix of $4 \mu \mathrm{l}$, template $(100 \mathrm{ng} / \mathrm{ul})$ of $1 \mu \mathrm{l}$, primer of $2 \mu \mathrm{l}$, milli $Q$ water of $3 \mu$ l. PCR was programmed for 25 cycles of initial denaturation at $96^{\circ} \mathrm{C}$ for 5 minutes, denaturation at $96^{\circ} \mathrm{C}$ for 30 seconds, hybridization at $50^{\circ} \mathrm{C}$ for 30 seconds and elongation at $60^{\circ} \mathrm{C}$ for 90 seconds. The sequence obtained was later compared against available database of $16 \mathrm{~S}$ rDNA using the Basic Local Alignment Search Tool (BLAST) from National Center for Biotechnology Information (NCBI) for its identity. The data was then submitted to NCBI to obtain a GenBank accession number MG768972.

\section{Molecular phylogenetic analysis}

The 16S rDNA gene sequence obtained from the isolated bacteria was subjected to phylogenetic analysis using MEGA $X$. The evolutionary history was inferred using the Neighbor-Joining method (Li et al. 2017).

\section{RESULTS AND DISCUSSION Morphological and Biochemical characteristics of Pseudomonas putida TS 18}

Identical colonies of gram -ve, rod shaped, motile and capsulated bacterium was obtained on nutrient agar after incubating the plates for $24-36$ hours at $28 \pm 2{ }^{\circ} \mathrm{C}$. The colonies were creamish yellow in color, entire form, elevation raised, margin smooth, opaque and motile. Biochemical characterization showed presence for catalase, oxidase and positive reactions for glucose, mannitol and citrate utilization and negative for other tests (Table 1 ). Thus indicating that the isolate plays a significant role in colonizing the host plant competitively by its flagellar activity and thereby utilizing different kinds of carbon source (Turnbull et al. 2001; Weisskopf et al. 2011). White pellicles of microaerophilic, gram -ve, and rod shaped, motile bacteria was obtained on $\mathrm{Nfb}$ semisolid media. Pellicles were formed after incubating the tubes at $28 \pm 2^{\circ} \mathrm{C}$ for $7-10$ days. Thus indicating the isolate is capable of fixing atmospheric nitrogen micro aerobically under in vitro conditions.

This is the first study aimed at understanding the role of associative symbiosis of alkalophilic nitrogen fixing bacteria present in water calyx fluid of $S$. campanulata. Flowering phenomenon of S. campanulata is interesting and unique. The uniqueness of the plant is production of water calyces which often contains watery fluid. The presence of reported bacteria adds to its peculiarity. The development of the floral whorls under bathing alkaline fluid of $\mathrm{pH} 8.5$ is unique among all flowering plants. The alkaline condition of the fluid would have further increased by the identified bacteria and it could be one of the reasons for the ammonical nature of calyx fluid which was reported earlier (Martin PA, et al. 2019). The amino acid pool in the calyx fluid would have also been enhanced by the identified bacteria as nitrogen fixers are known to contribute to amino acid production, other nitrogenous compounds required for chlorophyll containing organisms (Gonzalez-Lopez et al. 1995; Takuji et al. 2017; Ronald, 2001; Jayanthi et al. 2019).

Nitrogen fixing is considered to be second most vital process occurring in plants after photosynthesis influencing primary productivity (Rao, 2014). Nitrogen fixing is an important plant growth promoting character exhibited by the plant growth promoting rhizobacteria. It is well known fact that even Proteobacteria members like Pseudomonas can fix atmospheric nitrogen (Yongliang et al. 2008). Many authors have also proven that $P$. putida strains can fix nitrogen under natural and induced conditions (Yongliang et al. 2008; Ran et al. 1987; Chan et al. 1944; Setten et al. 2013; Li et al. 2017). In the present study the isolate showed $99 \%$ homology to $P$. putida $\mathrm{H} 8234$. The complete genome sequence of $P$. putida $\mathrm{H} 8234$ reveals presence of nitrogen metabolism, nitrogen fixation proteins coding for $\mathrm{NifU}$ and other similar related proteins (KEGG). Since, the isolate shows very close similarity to $P$. putida $\mathrm{H} 8234$, probably identified bacterial strain may be involved in fixing molecular nitrogen to ammonia and thereby helping in inner floral whorl development. The anaerobic environment created by the gamosepalous condition must be an ideal advantage for oxygen liable nitrogenase enzyme. In the present study, the microaerophilic culture conditions exhibited by the isolated bacteria are correlating with other studies as nitrogenase is reported to be functioning even at microaerobic conditions. (Mus et al. 2006). The isolate has also other plant growth enhancing traits which are not reported here. 


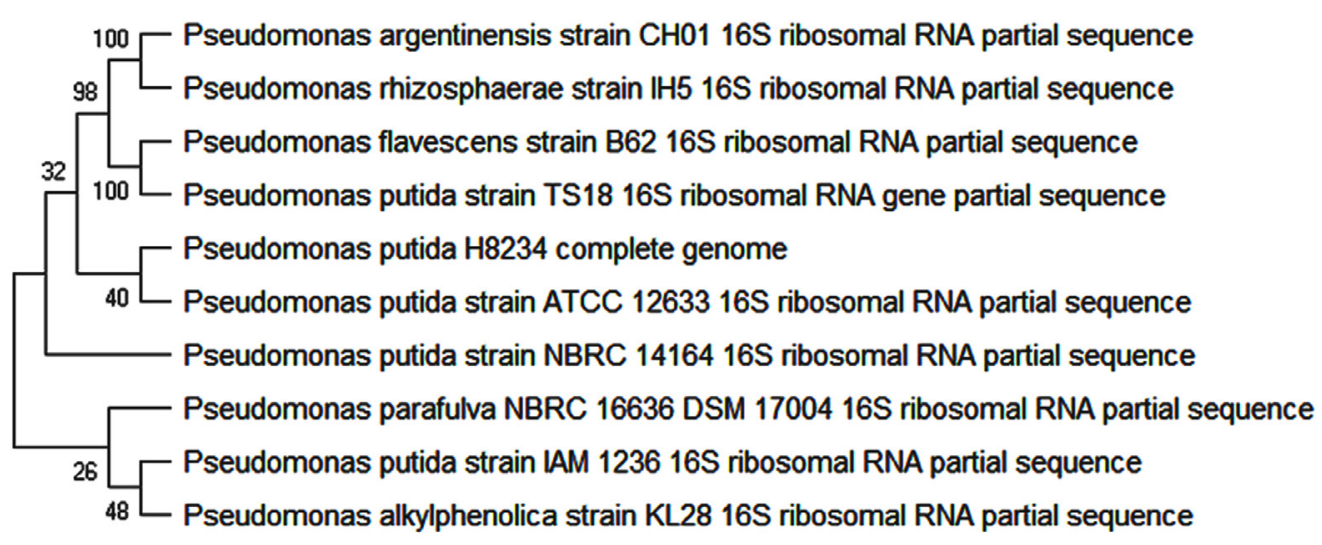

Fig. 2. Phylogenetic tree of Pseudomonas putida TS 18.

For any given plant, flowering is a complex and energy driven event and in cases like $S$. campanulata where it is exuberant and rapid, the nitrogen assistance provided by the bacteria will definitely be an additional source of nitrogen for the host plant (Salvagiotti F, et al. 2008). There are evidences showing nitrogen fixation is at peak during flowering (Lahiri K, et al. 2004). Additionally it has be shown that nitrogen fixation occurs till most of the seed fill period and the nitrogen is primarily transported into developing seed as glutamine and asparagine leading to the synthesis of seed proteins which is undoubtedly the reason for $S$. campanulata to produce hundreds of seeds in one single capsule (Rainbird RM, et al. 1984).

\section{CONCLUSION}

This is the first ever report on the presence of bacteria in the water calyx fluid of $S$. campunulata. The plant and the bacteria seem to be evolving as proto co-operative or a primitive associative organisms. The uniqueness of Spathodea campanulata flower development itself is its water calyx structure. The occurrence of the bacteria inside these structure perhaps should be influencing the flowering peculiarity with the developing floral buds pumped with dual sources of endogenous nitrogen.

\section{ACKNOWLEDGEMENTS}

The authors are thankful to St. Joseph's College (Autonomous), Bengaluru for providing us lab facilities in carrying out research work. We extend our thanks to Mr, Madappa, Dr. Jayashankar
M, Dr. Neelam Mishra and Dr. Lokesh Ravi, St. Joseph's College (Autonomous), Bengaluru for their critical inputs.

\section{CONFLICT OF INTERESTS}

The authors declare that there is no conflict of interest.

\section{AUTHOR'S CONTRIBUTION}

MP and JD conducted laboratory experiments. All authors have borne the expenses incurred during the study. All authors have contributed in preparation of the manuscript intellectually.

\section{FUNDING}

None.

\section{DATA AVAILABILITY}

Bacterial 16s rDNA gene sequence available under the mentioned Genbank accession number.

\section{ETHICS STATEMENT}

This article does not contain any studies with human participants or animals performed by any of the authors.

\section{REFERENCES}

1. Jane EC and Kyle EH. The benefits of bathing buds: water calyces protect flowers from a microlepidopteran herbivore, biology letters Biol Lett., 2007; 22:3(4): 405-07. https://doi.org/10.1098/rsbl.2007.0095

2. Burck W. Contribution to the knowledge of watersecretion in plants. II. Secretion of water in the flower, 
in: KNAW, Proceedings, 12, 1909-1910, Amsterdam, 1910; 400-417.

3. Killedar SG, Kope KI, Sangle SB, MS Tamboli. Standardization and Antimicrobial Activity of Watery Fluid at Floral Base of Spathodea campanulata (Pal) Asian Journal of Pharmaceutical Analysis, 2011; 1(1):19-21.

4. Pat Willmer. Pollination and Floral Ecology. Princeton University Press, New Jersey. 2011; 771. https://doi. org/10.23943/princeton/9780691128610.001.0001

5. Monica R and Esperanza MR. Bacterial Endophytes and Their Interactions with Hosts. MPMI, 2006; 19(8): 827-37. https://doi.org/10.1094/MPMI-19-0827

6. Gail MP. Plant perceptions of plant growth-promoting Pseudomonas. Phil. Trans. R. Soc. Lond. B., 2004; 359: 907-18. https://doi.org/10.1098/rstb.2003.1384

7. Vessey JK. Plant growth promoting rhizobacteria as biofertilizers. Plant Soil, 2003; 255: 571-86. https:// doi.org/10.1023/A:1026037216893

8. Silva VN, Silva LESF, Figueiredo MVB. Performance of Rhizobia with rhizobacteria that promotes plant growth in cowpea crop (Vigna unguiculata [L.] Walp)]. Acta. Sci. Agron., 2006; 28: 407-12. https://doi. org/10.4025/actasciagron.v28i3.964

9. Podile AR and Kishore GK. Plant growth-promoting rhizo-bacteria. In: Gnanamanickam SS (ed) PlantAssociated Bacteria. Springer, Netherlands, 2006; 195-230. https://doi.org/10.1007/1-4020-4538-7_6

10. Tasic S, Kojic M, Obradovic D, Irena Tasic. Molecular and biochemical characterization of Pseudomonas putida isolated from bottled uncarbonated mineral drinking water. Arch. Biol. Sci., Belgrade, 2014; 66(1): 23-28. https://doi.org/10.2298/ABS1401023T

11. Wafa H, Mohamed N, Hanene C, Afef N, Habib C, Rim CD et al. Pseudomonas rhizophila S211, a New Plant Growth-Promoting Rhizobacterium with Potential in Pesticide-Bioremediation. Front. Microbiol., 2018; 9(34): 1-17. https://doi.org/10.3389/ fmicb.2018.00034

12. Bernard RG. Plant Growth-Promoting Bacteria: Mechanisms and Applications. Scientifica. 2012;15. https://doi.org/10.6064/2012/963401

13. Islam S, Akanda AM, Prova A, Islam MT, Hossain MM. Isolation and Identification of Plant Growth Promoting Rhizobacteria from Cucumber Rhizosphere and Their Effect on Plant Growth Promotion and Disease Suppression. Front. Microbiol., 2016; 6: 1360. https:// doi.org/10.3389/fmicb.2015.01360

14. Charyulu NVN, Rao KVN. Changes in the nitrogen metabolism during growth and development of the flower in Spathodea companulata Beauv. Indian J. Plant Physio., 1990; 33(1): 7-15.

15. Trigo JR, Santos WF Dos. Insect Mortality in Spathodea Campanulata Beauv. (Bignoniaceae) Flowers. Rev. Brasil. Biol., 2000; 60(3): 537-38. https://doi. org/10.1590/S0034-71082000000300019

16. Martin Paul A, Jayanthi D, Thamizhseran N. BioPhysicochemical Studies on Water Calyx Fluid in the African Tulip Tree, Spathodea campanulata P. Beauv. Pharmacog. J., 2019; 11(3): 594-9. https://doi. org/10.5530/pj.2019.11.94

17. Jayanthi D, Martin Paul A, Thamizhseran N. Biochemical
Changes During Flowering of Spathodea campanulata P. Beauv. Pharmacog J. 2019;11(4):842-7.

18. James GC, Natalie S. Microbiology a laboratory manual, $4^{\text {th }}$ edt. Addison Wesley. 1999; 59-75.

19. Turnbull GA, Morgan JAW, Whipps JM, Saunders JR. The role of bacterial motility in the survival and spread of Pseudomonas uorescens in soil and in the attachment and colonization of wheat roots. FEMS Microbiol. Ecol. 2001; 36: 21-31. https://doi.org/10.1016/S01686496(01)00114-3

20. Weisskopf L, Heller S, Eberl L. Burkholderia species are major inhabitants of white lupin cluster roots. Appl. Environ. Microbiol., 2011; 77: 7715-20. https://doi. org/10.1128/AEM.05845-11

21. Rao DLN. Recent Advances in Biological Nitrogen Fixation in Agricultural Systems. Proc Indian Natn. Sci. Acad., 2014; 80(2): 359-78. https://doi.org/10.16943/ ptinsa/2014/v80i2/55114

22. Yongliang $Y$, Jian $Y$, Yuetan D, Ming C, Shuzhen P, Junping $\mathrm{P}$ et al. Nitrogen fixation island and rhizosphere competence traits in the genome of root-associated Pseudomonas stutzeri A1501. PNAS. 2008; 105(21): 7564-69. https://doi.org/10.1073/pnas.0801093105

23. KEGG PATHWAY Database. [Internet]; cited 03/05/2019. Available from: https://www.genome.jp/dbget-bin/ get_linkdb?-t+alldb+gn:T02706 accessed 03/05/2019.

24. Mus F, Crook MB, Garcia K, Garcia Costas A, Geddes $B A$, Kouri ED et al. Symbiotic nitrogen fixation and the challenges to its extension to non legumes. Appl. Environ. Microbiol., 2006; 82: 3698-710. https://doi. org/10.1128/AEM.01055-16

25. Ran L, Joseph WK, Maya K, Catherine S, John C, Elizabeth MT et al. Growth promotion of canola (rapeseed) seedlings by a strain of Pseudomonas putida under gnotobiotic conditions. Canadian Journal of Microbiology, 1987; 33(5): 390-95. https://doi. org/10.1139/m87-068

26. Chan YK, Barraquio WL, Knowles R. $\mathrm{N}_{2}$-fixing pseudomonads and related soil bacteria. FEMS Microbiology Reviews, 1944; 13(1): 95-117. https:// doi.org/10.1111/j.1574-6976.1994.tb00037.x

27. Setten L, Soto G, Mozzicafreddo M, Fox AR, Lisi $C$, Cuccioloni $M$ et al. Correction: Engineering Pseudomonas protegens Pf- 5 for Nitrogen Fixation and its Application to Improve Plant Growth under Nitrogen-Deficient Conditions. PLOS ONE, 2013; 8(10): 10.1371/annotation/279fe0d7-d9b1-4d05a45a-5ff00b4606b7. https://doi.org/10.1371/ annotation/279fe0d7-d9b1-4d05-a45a-5ff00b4606b7

28. Li HB, Singh RK, Singh P, Song QQ, Xing YX, Yang LT et al. Genetic Diversity of Nitrogen-Fixing and Plant Growth Promoting Pseudomonas Species Isolated from Sugarcane Rhizosphere. Front. Microbiol., 2017; 8: 1268.https://doi.org/10.3389/fmicb.2017.01268

29. Gonzalez-Lopez J, Martinez-Toledo MV, Rodelas B, Pozo C, Salmeron V. Production of amino acids by free-living heterotrophic nitrogen-fixing bacteria. Amino Acids, 1995; 8(1): 15. https://doi.org/10.1007/BF00806540

30. Takuji O, Norikuni O, Kuni S, Yuki O, Kotaro T, Manabu $\mathrm{U}$ et al. Amino Acid Metabolism and Transport in Soybean Plants, Amino Acid - New Insights and Roles in Plant and Animal, Toshiki Asao, Md. Asaduzzaman, 
Intech Open, 2017; 171-96. https://doi.org/10.5772/ intechopen.68992

31. Ronald FF. Nitrogen in the Environment: Sources, Problems and Management. Elsevier BV, 2001; 17-44. https://doi.org/10.1016/B978-044450486-9/50004-2

32. Jayanthi D, Martin PA and Thamizhseran N. Dual source phytohormones involved in flowering of Spathodea campanulata P. Beauv. Jr. of Pharmacognosy and Phytochemistry, 2019; 8(3): 3517-23.

33. Lahiri K, Chattopadhyay S, Ghosh B. Correlation of endogenous free polyamine levels with root nodule senescence in different genotypes in Vigna mungo
L. J. Plant Physiol., 2004; 161(5): 563-71. https://doi. org/10.1078/0176-1617-01057

34. Salvagiotti F, Cassman KG, Specht JE, Walters DT, Weiss A, Dobermann A. Review Nitrogen uptake, fixation and response to fertilizer $N$ in soybeans: a review. Field Crops Res., 2008; 108: 1-13. https://doi.org/10.1016/j. fcr.2008.03.001

35. Rainbird RM, Thorne JH, Hardy RW. Role of amides, amino acids, and ureides in the nutrition of developing soybean seeds. Plant Physiol., 1984; 74(2): 329-34. https://doi.org/10.1104/pp.74.2.329 